凟料

\title{
日本原子力研究所における放射線測定器の
}

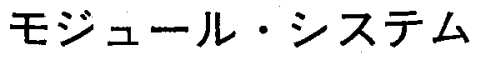

金 原 節 朗*, 熊 原 忠 士*

（1969年9月12日 受理）

\section{Nuclear Instrument Modules in the Japan Atomic Energy Research Institute}

By Setsuro KINBARA and Tadashi KUMAHARA

\begin{abstract}
Technical information on the nuclear instrument module system used in the Japan Atomic Energy Research Institute (JAERI) for general nuclear experiments is presented. This JAERI module system accords with the NIM standard adopted in 1966 by the U.S.AEC. Already in JAERI nearly 1,000 units of the module representing 47 varieties, have been produced and supplied to various laboratories in JAERI. The module system possesses many features embodied in the pulse shape discriminating circuit, the time pickoff circuit and the high resolution spectrometry system. A description is given of these features, as also of the circuit configuration and characteristics of these units, which include general purpose nuclear instruments.
\end{abstract}

\section{1.はしがき}

放射楾計测はパルスの計数から始まり，シングルチ ナネル・アナライザからマルチチャネル・アナライザに よる测定へと発展し，エネルギー分布の测定に限らず 時間分布や粒子弁別等の複雑な測定が一般に行われる よ5になってきている。また，エネルギー分布の測定 ては，半導体検出器の進歩により测定精度が飛躍的に 向上し，雑音特性や安定度のよいるのが要求されるよ 5 になり，全般的に測定系の多様化と高度化が行われ ている。

放射線测定器の形態は，真空管時代からすでにモシ ニール化が行われており，1957年に Hawell(英)て 2000シリーズの標準化を行なっている。しかし，モシ ュール化が一般に考劣られるようになったのは，1960 年前後からトランジスタ化が急速に進んで小形化が可 能になって，従来の19゙パネル・シャーシを縦割りにし た，いわゆるモジュールが一般に用いられるようにな り，その標準化が必要になってからである。1961年に EURATOMで“ESONE”規格(1)が制定され，つづいて 1964年には U.S.AEC でNIM”規格(2)を制定してい る。その他各機関毎の規格は非常に多く現われている が，一般性のあるbのは上記 2 規格が代表的なるのて
ある。これらの規格はその後順調に発展し, 前者はヨ ーロッパの一部で，後者はアメリカを中心に世界的に 普及し，わが国ても NIM 規格が一般的に使われるよ 5になっている。

NIM 規格のモジェール・システムは Photo. 1 に示 すように高さ $83 / 4 "\left(5 \frac{1}{4} / \|\right.$ るる), 幅19"のビンに単位幅 (34.4n-0.1)のモジュールが 12 個插入できるようにな

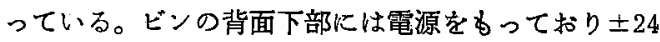
$\mathrm{V}, \pm 12 \mathrm{~V}, \mathrm{AC} 115 \mathrm{~V}$ が用意されている。モジニールと ビンとの電気的接続は同軸コネクタ 6 個を含さ 42 ピン のコネクタで接続され，広い分野に適用できるよう考 㦄されている。一般放射䠌測定用のモジュール・シス テムでは，上記の標準コネクタからは電源だけが供給 され，信号は前面および背面パネルにコネクタを設け て直接出し入れするようにしている。そのため構造お よび電源関係が規格に合っていれば，任意の位置に任 意のメーカーで作られた任意の機能のモジニールを捧 入することができ，きわめて高い互換性をるっている。 原研ては内外の情势を検討し，1966年に放射線湘定 器の標準形熊として U.S.AEC の NIM 規格を探用す

* 日本原子力研究所(Japan At. Energy Res. Inst.) 


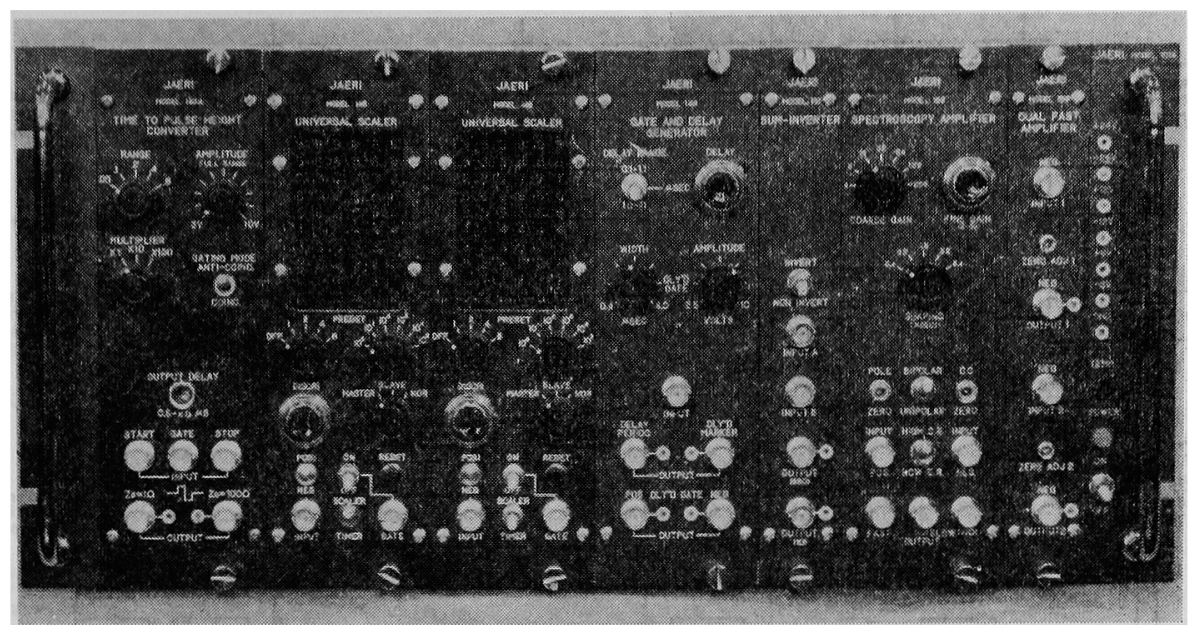

Photo. 1 Front view of the typical module system

ることにし、NIM 規格に準拠した“原研型モシュール． システム”(3)を制定した。そしてビン電源を初め一般放 射線測定系を中心に，高分解能測定系や時間測定系， 波形弁別系等を開発してきている(1) -(8)。現在(1969 年 8月)までに47機種が開発され，約 1,000 台が製作され ている。

原研に抽るモジュール・システムは，需要が原研 内の研究や業務範囲に限られているので, 種類は低エ ネルギー関係のるのが主で，その中でるスロー系を中 心に開発してきている。その中で特徴となる点を述べ ておくと，测定対鱼となる情報を整理し，波高，時間， 波形，計数といった基礎情報が容易に测定できるよう に考虑されている。特に波形情報の測定は一般には特 殊測定の扱いをされているが,原研型モジュール・シス テムの中では一般のディスクリと同等の容易さで扱う ことができる(9000。㭙間検出(11)(12)やべース・ライ ン再生回路に独特な方式を持っており，各ニニットの 随所に適用して性能の向上を計っている。さらに，半 導体検出器の発展に対処して10-4 以下の測定精度を目 標にした高分解能測定系の開発を進めている(13) (15)。 その他一般的な機能回路は任意の测定系を組むことが でさるように各種用意してありこれらは極力 IC 化 る゙行なって性能や信頼度の向上を計っている(16)(17)。

以下原研型モジニール・システムについて, 系統別招 よび類似用途のグループ別に主なるのを紹介したい。

2. 放射線測定系の柾成とモジュール・システム

放射線の測定系は，基本的には検出器で得られたパ ルスをプリアンプ,リニヤ・アンプで増幅し，アナライ ザで測定することで構成される。この基本形に対し付
属的な高圧電源や，測定目的を拡大するための種々な 機能回路，さらに測定精度を向上するための補助回路 等が加わり，それらを種々組み合わせて実際的な湘定 系が構成される。このよ5な測定系のうち検出器と丁 ナライザを除く部忽がモジュール化されている。

剆定系の構成をエレクトロニクス的立場からみると. Fig. 1 のよになり，ハルス系では波高, 時間, 波形, 計数の基碟情報が測定対象となっている。また信号の 流れからみて, 検出器部, 増幅部, 情報の検出部, 時間; 処理部，領域の選択部，相互制御部，剆定部等に分けら. れる。

原研型モジュール・システムはFig. 1 の測定系が満 足に構成されるよ 5 各種のモジュール・コニットが開 発されて括り，その Model 番号を各ブロックの右下 に示した。

Fig. 1 を簡単に説明すると, 検出器からの出力パ ルスはプリアンプやリニナ・フンプで増幅され，その 直後で目的とする情報の検出を行う。その後で特に時: 間関係の処理を行い,アナログ量への変換す行われ る。次に，情報の相互処理を行 5 ため各情報の領域選 択を行い，つついて相互処理を行なって測定系に信号 を送っている。Fig. 1は機種を整理した形でまとめて あるが，実際の測定系ではさらに複雑で重複したるの となる。

各モジュール・ニニット間のパルス信号は,アナログ 情報をるったりニヤ・パルスとロジック・パルスとに分

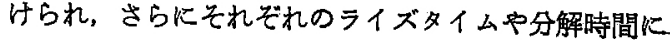

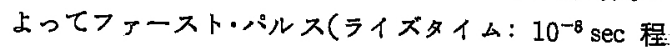
度、分解時間: $10^{-7} \mathrm{sec}$ 程度以下)とスロー・ハルスに 


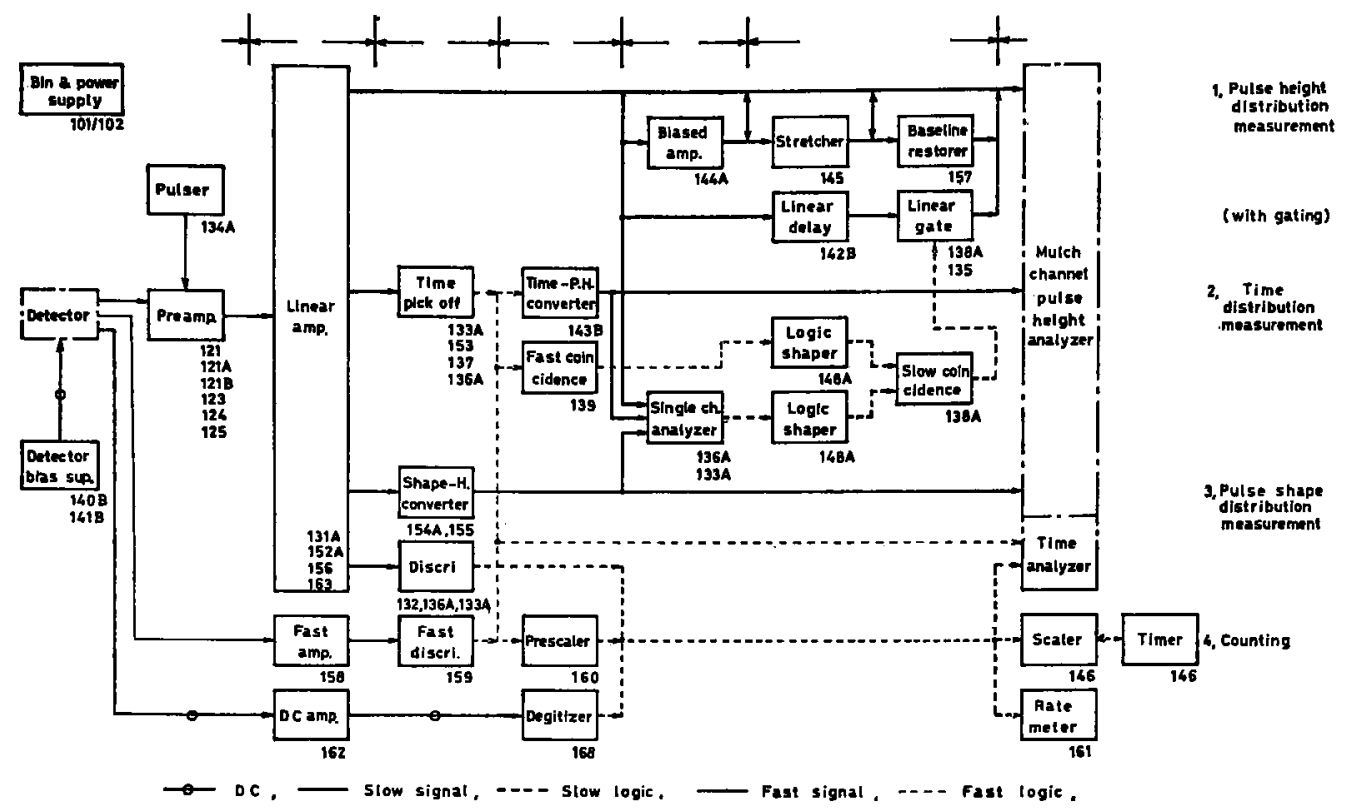

Fig. 1 Systematic diagram of nuclear instruments by the module units

分けられる。ファースト・ハルスはリニヤ系では振幅 が $0 \sim-1 \mathrm{~V}$ ，ロジック系では振幅がー18 $\mathrm{mA，パル}$

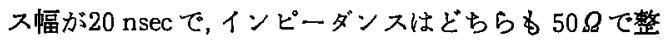
合をとるようにしている。スロー・パルスは,リニヤ系 は振幅が $0 \sim+10 \mathrm{~V}$, ロシック系は振幅が+5V, パ

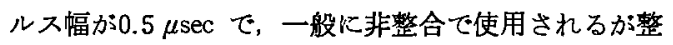
合される場合は $93 \Omega$ としている。

各モジュール・ュニットは $1 〜 3$ 倍幅のモジュール に納めているが, その大きさは, 回路の密度とパネル面 に取り付けられる部品面積を基準にして決めている。 現在まての製作例では，回路密度よりるむしろパネル 面の部品面積で制約されているすのが多い。

3. 検出器の周辺ユニット

放射線検出器の周辺には，検出器の種類や用途に応 じて，適当な特性を持つ検出器用高圧電源やプリアン プや較正用パルサ等を必要とする。

検出器用高圧電源は一般に $0 \sim \pm 3 \mathrm{kV}$ 程度の出力 電圧をるち, 特に半導体检出器用のるのでは雑音やリ ップルが少なく, シンチレーション検出器用のbので は長時間安定度や負荷変動率のよいるのが要求され る。Model 140B は一般の半尊体検出器やガス電離箱 用の高圧電源で, $0 \sim \pm 2 \mathrm{kV}$ の出力電圧て $3 \mathrm{mVPP}$ 以下のリップルおよび雑音特性をるっている。 Model 141B はシンチレーション検出器用の高圧電源で， 0.5 $\sim 1.5 \mathrm{kV}$ の出力電圧で $10^{-4}$ 以下の長時間安定度と負
荷変動率をるっている。Fig. 2 は, Model 141Bの簡 略回路を示したるので，他励型 $\mathrm{DC} \sim \mathrm{DC}$ コンパータ の入力電圧を IC( $\mu \mathrm{PC} 55 \mathrm{~A})$ を使った増幅回路で制衙 する方式としている。

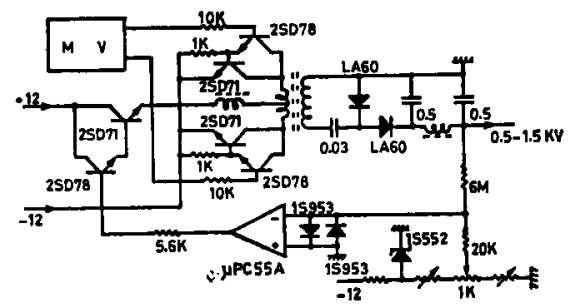

Fig. 2 Simplified circuit diagram of the Model $141 \mathrm{~B}$ detector high voltage supply

プリアンプは, 検出器の出力信号の信号対雑音比 $(S)$ N)やライズタイムの劣化を避けるために，检出器に 接近して取り付ける必要がある。のためモジュール •ニニットの形態がとれず， $154 \mathrm{~mm} \times 112 \mathrm{~mm} \times 44 \mathrm{~mm}$ の箱形構造となっている。特に半導体検出器用のプり アンプでは，雑音の少ないことが強く要求されてい る。Model 121 は室温動作の半導体検出器用の電荷増 幅型プリアンプで, $1.9 \mathrm{keV}+0.06 \mathrm{keV} / \mathrm{pF}$ (fwhm Si) の雑音特性を持っている。Model 121A はガス電離箱 や比例計数管用の電荷増幅型プリアンプで，高いバイ アス電圧に対する入力段保護回路が設けられ，3kV の耐圧をるている。Model I21B, Model 125は冷却 
動作の半賞体検出器用の䉓荷増幅型プリアンプで, Model 125 では $770 \mathrm{eV}+45 \mathrm{eV} / \mathrm{pF}$ (fwhm Ge) の雑音 特性をる， $10 \mathrm{nsec}$ 以下のライズタイムをるってい る。Model 124 はシンチレーション检出器用の電圧増 幅型プリアンプで, 光電子増倍管の出力パルスのディ ケイタイムが変えられるようになっている。これらの プリアンプは，すべて入力段に接合型電界効果トラン ジスタ(JFET)を使用して，低雑音と高入力インピー ダンス特性を得ている。Fig. 3 に Model 125 の回路 櫼成を示す。

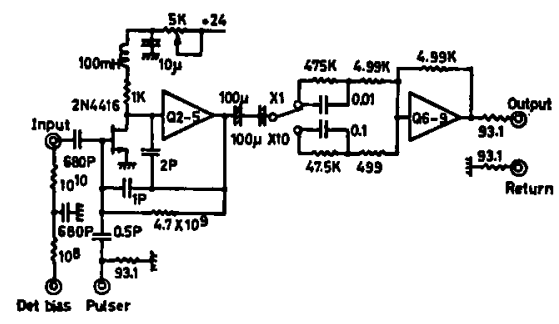

Fig. 3 Simplified circuit diagram of the Model 125 fast charge sensitive preamplifier

Model 134 A は, 测定系の直線性や雑音特性, 動作試 験等に使用されるパルサで，ライズタイムとフォール タイムがそれぞれ 10〜250 nsec, 50〜 400 $\mu$ seck変えら れるようになっている。

\section{4. 增幅ユニット}

検出器で得られたパルスを処理しやすいレペルまで 堌幅するリニア・アンプは, 種々の検出器や测定目的 に適用できるように，広い範囲のゲイン・コントロー ルとパルス整形かでることが必要であり，さらに 高分解能中高精度の測定に適するよう，雑音特性，安 定度, 直線性のよいことが要求される。 $S / N$ や時間分 解能を改善するためのパルス整形には，CR-RCフォ ルタやディレイライン・クリッピングやアクティブ・フ イルタ等が用いられこれらの時定数はシンチレーシ ヨン檢出器では $0.1 \sim 1 \mu \mathrm{sec}$, 半導体检出器では $1 \sim 5$ $\mu \mathrm{sec}$, 比例計数管では $2 \sim 10 \mu \mathrm{sec}$ の範国方使用され る。リニア・アンプとしてはそれぞれの用途に応じて， Model $131 \mathrm{~A}$ マルチモート゚・アンプ, Model 152A ダ ブル・ディレイライン・アンプ, Model 163 リ アア・ア ンプ等が使用される。

Model 131A はるっとる広く使われるるので,ゲイ ンが0.4〜500で, $0.1 〜 10 \mu \mathrm{sec}$ に時定数を変えられる 2 段の CR 微分フィルタとI段の積分フィルタを るち，さらに $0.8 \mu \mathrm{sec}$ のシングルまたはダブル・ディ
レイライン整形が行えるようになっている。このアン プの最少ライズタイムは100 nsec 以下で，入力等価雑 音は $8 \mu \mathrm{V}$ 以下, 安定度は $0.01 \% /^{\circ} \mathrm{C}$ 以下で, $0 \sim+$ $10 \mathrm{~V}$ の出力パルに対して $0.1 \%$ 以下の直線性をる っている。

Model 152A は，ゲインが0.4〜500で 0.2〜1.6 $\mu \mathrm{sec}$ のシングルまたはダブル・ディレイライン整形がで き，さらに外部のディレイラインによって任意時定数 の整形るできるよ5になっている。Fig.4 4 は, Model 152A の整形回路を示したすので，堌幅回路の出力段

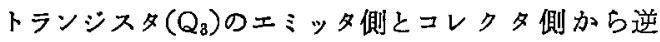
位相の出力をそれぞれ抵抗回路とディレイラインを経 て次の増幅段のサム・ポイントに接続している。この ときに負荷の不平衡による波形歪が生じない上5に Q4で補正作用を行わせている。

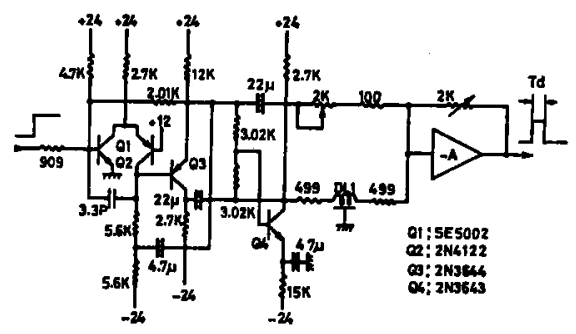

Fig. 4 Partial circuit diagram of the shaping circuit of the Model 152A double delayline amplifier

Model 163は IC 化された小型(単位幅)のリニア・ア ンプで, ゲインが 10〜500 で0.4〜1.6 $\mu \mathrm{sec}$ の CR-RC ${ }^{2}$ または $\mathrm{CR}^{2}-\mathrm{RC}$ 整形が行えるようになっている。この yニア・アンプの構成は Fig. 5 に示すよ 5 に, 入力 段と出力段を除く中間の増幅段に CA3030A を使用し て IC 化している。

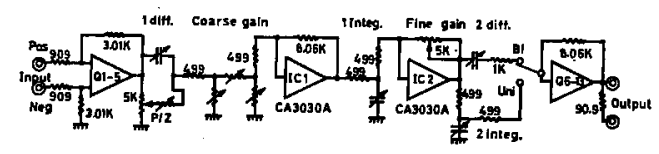

Fig. 5 Block diagram of the Model 163 linear amplifier

特に速い(<10 nsec) 時間情報や計数值を得たい場合 には，検出器の電流パルスをそのまま広帯域增幅する 方が適している。Model 158 テュアル・ファースト・ア ンプはこのような用途に適した增幅器で, ゲインが10 でライズタイムが 5 nsec以下の直結型広带域増幅器を 2 組内蔵している。Fig. 6 は Model 158 の回路を示 したもので, $0.1 \% 1^{\circ} \mathrm{C}$ 以の安定度とー $1 \mathrm{~V}$ 出力電 
生に対して士1\%以下の直線性をるっている。

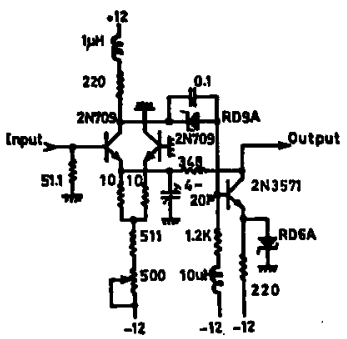

Fig. 6 Circuit diagram of the Model 158 dual fast amplifier

イオン・チェンバなどで放射線の強さに比例した微 少電流を測定する場合には，高感度の直流電流計が必 要となる。Model 162 は $10^{-12} \sim 10^{-3} \mathrm{~A}$ の範围の電流 を土 $3 \%$ 以下の精度で測定できる $\mu \mu \mathrm{A}$ 計で，K-302 のハイブリッド IC を使用して入力電流に比例した最 大 $\pm 10 \mathrm{~V}$ の出力電圧が得られるようになっている。 この出力電圧を Model 168 のカレント/ボルト・ディ ジタイザを使って最高繰返し周波数が $1 \mathrm{MHz}$ のパル スに変換すれば，一般の計数系でディジタル的に処理 することができる。

\section{5. 波高分布測定系のユニット}

検出器に生じた全電荷は放射線のエネルギーに正確 に比例するのでここの全電荷に比例した振幅をすつパ ルスの波高を測定することにより，正確なエネルギー 分析を行うことができる。現状ではマルチ・チャネル。 アナライザの普及により，マルチ・チ十ネル波高分析か 放射線計測の中心となっでいる。リニア・アンプでは 雑音レペルや計数率に応じて最適出力波形が選ばれる のに対して，アナライザにる最適入力波形が存在する ので，一般的にはこれらの間に Model 144A のバイ アスド・アンプや Model 146 のパルス・ストレッチャ, さらに Model 157 のベースライン・レストアラなどの 波形処理回路か挿入される。

Model 144A は, 雑音レペルの不要信号を除去した り，スペクトル分布の関心のある部分を拡大してアナ ライザに入れるためのすので，ハイアス・レベルの安 定なことと，非直線㤠の少ないことが要求される。

Fig. 7 は, Model 144A の簡略回路を示したもので, 安定度のよい能動回路によるべースライン再生回路と 可変スレッシュホールド増幅器とで構成され；0１00 \%のパイス・レベルと1〜20のダインをるち. 0.02\%1 ${ }^{\circ} \mathrm{C}$ 以下の安定度, $\pm 0.2 \%$ 以下直線性をるっている。 Model 145 は, 入力パルス幅の変化によってアナライ ザのスペクトル歪が生じるのを避けたり，狭いパルス
の測定を容易にするためのるので， $0.02 \% /{ }^{\circ} \mathrm{C}$ 以下の 安定度と $\pm 0.2 \%$ 以下の直線性をっている。Model 157 は，リ二ヤ信号が交流結合部を通過する時に生ず るべースラインの変動をおさえるためのすので，フナ ライザや種々の回路の入力電圧籍囲に適合するように 出力パルスのフルスケールを $\pm 3, \pm 6, \pm 10 \mathrm{~V}$ K巽べる 上うになって找り，高分解能測定系にも使用できるよ 亏K, $0.005 \% 1^{\circ} \mathrm{C}$ 以下のベースライン安定度と \pm 0.1 \%以下の直線性を㛡ている。

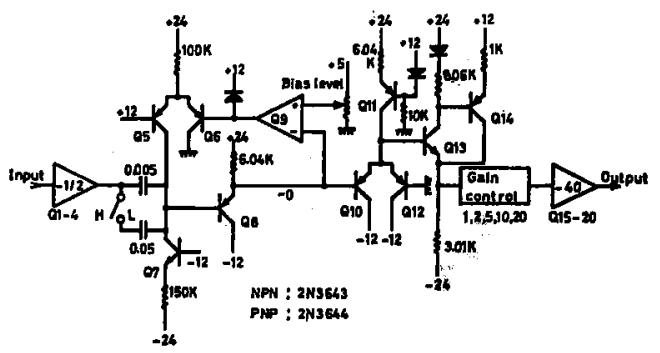

Fig. 7 Simplified circuit diagram of the Model 144A biased amplifier

上り精度の高い波高分析を行 5 ために，波高，時間， 波形などの情報で波高測定系を制御することが行われ る。この上5な場合には Model 142B のリニア・ディ レイであらかじめ被制御信号を数 $\mu \mathrm{sec}$ 遅らせておき， ファースト・コインシデンスやシングル・チャネル・フ ナライザの出力信号で Model 138A のリニ+・ゲート を制御し，選抧されたりニナ・パルスを通過させる必 要がある。

Model 142Bは,リニア信号を0.2 6.4 $\mu \mathrm{sec}$ 暒延させ ることのできるすので，リニア信号に特別な歪を加え ることのない上う考虑され，0.01\%/ ${ }^{\circ} \mathrm{C}$ 以下の安定度 と土0.1\% 以下の直線性をすっている。 Model 138A は選択可能な 5 個のロジック・パルスのスロー・コイン シデンスによってリニア・ゲートを動作させるすので， リニア信号化対する安定度は $0.02 \% /{ }^{\circ} \mathrm{C}$, 直線性 \pm 0.2 \%以下で, 入力信号のるれや不要信号は $100 \mathrm{mV}$ 以下 となっている。特に Model $138 \mathrm{~A}$ 汁計数率特性をよ くするために，入力部に能動型のペース・ライン再生 回路を使用している。

エネルギー分解能は，低エネルギー領域ではプリフ ンプの雑音か，高エネルギー領域では総合安定度が， さらに高計数率ではべースライン変動が大きな寄与を 与えるので，高分解能洌定にはこれらの分解能の劣化 を最少にする考虑が必要となる。Fig. 8 は，波高分 布測定系のうちで特に $\mathrm{Ge}(\mathrm{Li})$ や $\mathrm{Si}(\mathrm{Li})$ 検出器用の高 分解能スペクトル测定系の構成を示したすので，基本 
的には Model 123 の冷却型 FET プリフンプと， Model 156 のスペクトロスコピイ・アンプ，さらに Model 174 のゲーテッド・ハイアス・アンプで構成され ている。ここで Model 155，133A，148A は榆出器の デッド・レアで生ずるスロー・パルスや，高計数率での ピーク・パイルアップを除去するための波形弁別回路 を構成している。

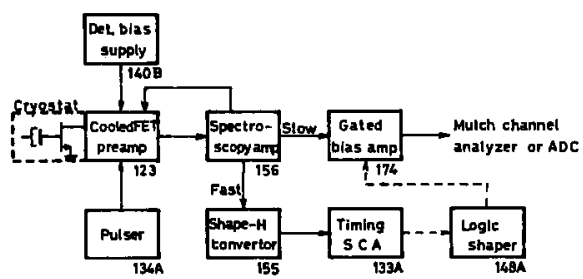

Fig. 8 Block diagram of the high resolution spectrometry system

Model 123 は、入力段 FET を検出器に直結とし， 検出器ととるに真空冷却槽内に設置する構造としてい る。このような構造をとることにより，ストレイ容量 や漏洩電流によって生ずる雑音や、マイクロホニック 雑音が最少となるだけでなく，FET 自体を適温 $\left(80^{\circ}\right.$ 〜 $\left.150^{\circ} \mathrm{K}\right)$ に冷却することができ，雑音特性が大きく 改善されて $500 \mathrm{eV}$ 以下の雑音特性が得られる。

Model 156 は, 能動積分回路を使った $0.4 〜 6.4 \mu \mathrm{sec}$ のガウシアン近似フィルタをるち, 入力等価雑音 $6 \mu \mathrm{V}$ 以下，安定度 $5 \times 10^{-5} /{ }^{\circ} \mathrm{C}$, 㨁線性 $\pm 0.02 \%$ 以下の特性 をるつ高安定堌幅器である。ここで用いているアクテ

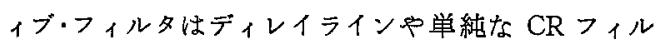
タにくらべて $S / N, 1 / f$ 杂隹音, ライズタイム変動, 分解時 間などの点ですぐれており，低雑音増幅に適してい る。

Model 174 は, 能動的なベースライン再生回路, ハイ アス堌幅器, ストレッチア、リニア・ゲート等の直結回 路で構成され， $S / N$, 安定度, 直線性に対する考慮がさ れている。

\section{6. 波高および時間検出用ユニット}

波高情報の検出と時間情報の検出とは別機能である が，両機能は相互に関連があり，両機能を同時に持っ たすのが使いやすく，なんらかの形で両機能を備えた あのが多い。波高検出を行うすのとしては，1つのデ ィスクリを持ったインテグラル・ディスクリModel 132 と，2つのディスクリを持ったタイミング・シングル チャネル・アナライザ Model $133 \mathrm{~A}$ ，シングルチャネ ル・アナライザ Model 136A 等がある。さらに早いパ ルス用には、ファースト・ディスクリ Model 159 があ
る。次に時間検出用には，専用のるのとしてリーデ ング・エッジ・゙ックオフ Model 153とクロス・オーハ・ ピックオフ Model 137があり，また上記 Model 133A と136Aはタイム・ピックオフ機能をる兼備したすので ある。

Model 132 は, 設定レペル以上の入力パルスをすべ て計数するインテグラル型動作で，ノイズ・レベルの 除去や簡単な計数回路のディスクリとして用いられ る。Model 133Aは, ウィンド・モードで動作させるこ とができ：シングル・チャネル・アナライザとして使う ことができる。また Model 133A は，時間検出用とし てる優れた機能をるって扣り，任意のハルスのリーデ ィング・エッジまたはバイポーラ・パルスのクロスオ 一バ点から正確な時間信号の検出ができる。出力パル スは，ディスクリで選択された波高範囲を正確な時間 信号て制御して出している。Model 136Aはこれる2 つのディスクリをるって括り，この2つを使い分けて デュアル・ディスクリやディファレンシャル・モード, ウィンド・モードのシングル・チャネル・アナライザと することができ，さらにロア・レベルを外部制御するこ とすできる。回路は主要部をIC化して招り，Fig.9に ベース・ライン再生回路とディスクリ回路を示す。時 間関係は，リーディングエッジからのタイム・ピック オフ回路または外部ストローブ・ハルスによって正確 な時間信号を得ることができ，シングル・チャネル・モ ードでは正確に時間制御が行われた出力が得られる。

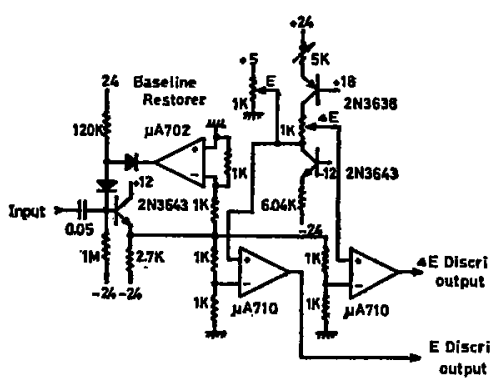

Fig. 9 Simplified input circuit diagram of the Model 136 A single channel analyzer

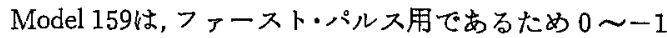
$\mathrm{V}$ の入力パルスに対して働き，10nsec のダブル・パ ス分解時間を持っている。このディスクリは定レペル 型であるが， 入力パルスのライズタイムが数 nsec 以 下であれば，出力パルスのタイム・シフトは数 n sec 以 下となる。

Model 153 は, リーディング・エッジから正確な特 


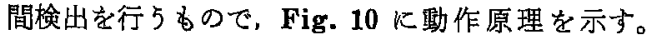
(Model 133A, 136A б同一原理)このモジュール・ュ ニットは特にピックオフのフラクション・レベルを外 部から変えられるようになっており，簡単なスレッシ ュホールド・ディスクリるついている。Model 137 は 一般的なバイポーラ・パルスからの時間検出に使われ るすのである。

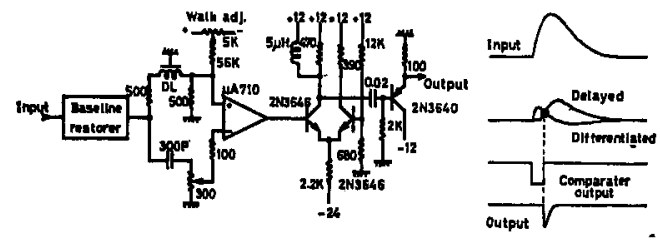

Fig. 10 Principle showing the leading-edge time pickoff circuit (applied for the Model 133A timing single channel analyzer, the Model 136A single channel analyzer and the Model 153 leading-edge time pickoff)

これらのモシュール・ニニットの一般特性は,ファ 一スト系を除いてほぼ共通で，入力は $0 \sim+10 \mathrm{VD二}$ ニポーラまたはパイポーラ・パルスに適用される。デ イスクリ・レベルは+0.1〜+10V以へリポットで変え られ,この直線性は $\pm 0.5 \%$ 以下, 特間検出のウォーク 特性は10: $1(8 \sim 0.8 \mathrm{~V})$ で士 $2 \mathrm{nsec}$ 以下，感度は0.15V 以下を保証している。

\section{7. 時間処理ユニット}

数 $\mathrm{nsec}$ 以下の精度で検出された時間信号は，タイ ム・アナライザのスタート,ストップの信号として使わ れたり，時間波高変換やファースト・コインシデンス にる使われる。Model 143B のタイム・ッー・バル・ ハイト・コンパータは時間情報を波高情報に変換し，一 般的な波高分析器で時間分布を測定するときに用いら れる。Model 143Bは50 nsec〜80 $\mu \mathrm{sec}$ の時間間隔を フルスケール+3〜+10Vk変換するすので，その間 の直線性は出力の 10〜100\%の間で士0.1\%以下となっ ている。

Model 139 のァースト・コインシデンスの用途は, 物理現象の同時性を検出するすので，10〜110 nsecの 分解時間をむっている。入力端子は 3 個用意されてい るが，スイッチによって任意にはずすことができ，ダ ブルまたはトリプル・コインシデンスが行える。分解 時間はへリポットで上記範囲を任意に設定できる。 出力は＋5Vのスロー・ロジック・バルス扔出されてい る。ュインシデンス回路は，このほかに Model 138A のスロー・コインシデンスがあり，これは現象扰よび
エレクトロニクス回路で生ずる時間のバラッキを含め て同時性を検出するすので，分解時間は入力パルスの 幅に依存し，一般に $1 \mu \mathrm{sec}$ 前後である。

スロー・コインシデンス等岁行うとき，各测定系か らのロジック・ハルスの位相を合わせるため， Model 148Aのロジック・シェーパ・アンド・ディレイが用いら れる。これは一種のディレイ・ジェネレータて，0.1〜 $110 \mu \mathrm{sec}$ の遅延を与学ることができ，出力パルスは正 負同時に得られ，振幅は $2.5 \sim 10 \mathrm{~V}$, 幅は $2 \sim 10 \mu \mathrm{sec}$ が任意に出せるようになっている。

\section{8. 波形処理ユニット}

原研型モジュール・システムのうちでるっとる特徴 の屯るるので，前記したように波形弁別が一般のディ スクリと同様の容易さで行うことができる。波形弁別 ニニットは, ライズタイム・ッー・ハイト・コンバータ Model 154A と,シェープ・ッー・ハイトコンパータ Model 155 で, 前者は任意のパルスのライズタイムを 波高無関係に测定し，ライズタイムに比例した波高 出力を出す。後者は任意のパルスのライズタイム括 びパルス幅を波高に無関係に測定し，同じく波高の出 力を出するのである。Fig. 11は, Model 155 の原理を 示すブロック・ダイヤグラムと動作波形で, コンパレー タ 1 は Fig. 10 と同一動作による時間原点の検出を行 い,コンパレータ 2 では S岸開いているときディレ一 ド・パルスと $\mathrm{R}_{2}$ によって適当に隇衰を行なったパル スが加えられ，両者の交点からライズタイムに比例し た時間信号が検出され，時間原点との時間差を波高に 変換して，ライズタイムに比例した波高出力が得られ る。またコンパレータ 2 です閉じた場合はディレイ ド・パルスに積分がかかり，動作波形に示されるよう に $\mathrm{R}_{2}$ から加えられるパルスの尾部の時間を検出し， 時間原点との差はパルス幅に比例することになる。各 コンパレータの動作点は基準レベルが一致しているの で波高の大小には無関係で，波形差だけを検出するこ

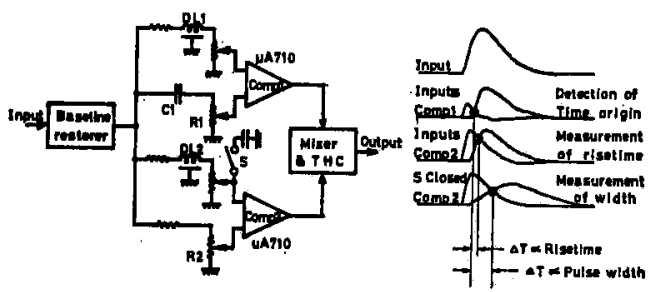

Fig. 11 Principle showing the pulse shape discriminating circuit (Applied for the Model 154A risetime to height convertor and the Model 155 pulse shape to height convertor) 
とができる。また，各設定点は入力パルスの条件に応 じて適当に変えられるように可変となっており，0.1〜 $10 \mu \mathrm{sec}$ の広い波形箸囲にわたって適用することがて きる。Model 154A すほぼ同様の動作原理であるが， ライズタイムを専用に测定する。2つのコンパレータ 回路は全く同様に作ってまり，検出点を任意のフラク ションに設定でき，入力パルスの立上り部分の任意の 部分を剆定できる。

その他の機能は，両者共にアッパーレベル・ディス クリとロアレベル・ディスクリを持っていて，エネル ギーの特定領域を選定できる。入力範囲は测定対象

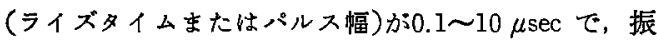
幅は+0.2〜+10V，波形はパイポーラ,ニニポーラ等 任意に適用できる。電圧特性は $20: 1(+10 \sim+0.5 \mathrm{~V})$ で士 $1 \%$ 以下，温度安定度 $0.1 \%{ }^{\circ} \mathrm{C}$ 以下が得られる。

これらのニニットは，出力がアナログ量で得られる ので定量的な解析に用いることができ，マルチパラメ 一夕測定にる有用である。Fig. 12 は，Model 154A を用いた有機シンチレータによる $\mathrm{n}-\gamma$ 弁別の測定例 で、ライズタイム分布を示している。Fig. 13 は, シ リコン・サーフェス・ヘリヤ検出器で ${ }^{8} \mathrm{Li}(n-\alpha) \mathrm{T}$ 反応 を測定したときの $\alpha$ 線のエネルギー分布て， Model 154A による波形弁別を行なった時と行わない時を示 しており，効果が顕著に現われている。

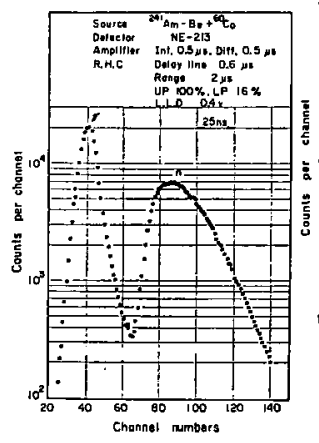

Risetime distribution of the NE-213 and the photomultiplier for the mixed radiation source by the Model 154A

Fig. 12

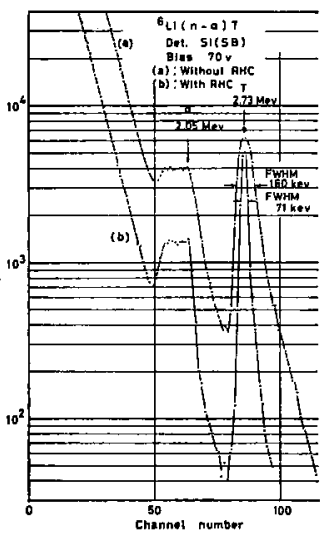

Pulse height distributions of the surface barriar $\mathrm{Si}$ detector for the ${ }^{B} \mathrm{Li}$ $(n-\alpha) T$ reaction with or without pulse shape discrimination by the Model 154A

Fig. 13

\section{9. 計数系ユニット}

計数系はスケーラ兼タイママのコニホーーサル・スケー
ラ Model 146 と, $100 \mathrm{MHz}$ 以上の計数速度を持つプ リスケーラ Model 160がある。Model 146は Photo. 1 に外観が示されているか，計数容量 10 進 6 桁，計数速 度最大 $15 \mathrm{MHz}, 0 \sim \pm 10 \mathrm{~V}$ のインテグラル・ディス クリを内蔵しプリセットすでる。タイマとして使用

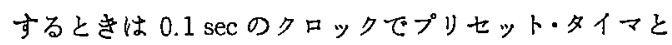
なる。動作モードは，単独の動作をさせるノーマル・ モードのはが，数個のスケーラを組み合わせて動作 させ，そのグループのマスターあるいはスレーブとし て任意使えるようになっている。さらに、リード・ アウト・コントロール(Model 147)と組み合わせてデ 一タのプリント・アウトる可能である。 Model 160 は Model 146 のプリスケーラとなるるので, 計数容量は 10進 1 桁, 速度は100 MHz 以上で動作モードは Model 146 と合わせてある。

計数系としてはこのほか Model 161 のレートメー タがある。Model 161 はリニヤとログの両用で, リ二 ヤ・レートメータとしては $10^{5} \mathrm{~Hz}$ まで，ログ・レートメ ータとしては106 $\mathrm{Hz}$ まで計数でき，メ一タ表示をする ととすにレコーダ出力出している。

10. 回路のIC 化

モジュール・システムの開発に当っては回路の IC 化ということを1つの要点として行なって来ている。 現状では回路の全面的 IC 化とい5段階に至っていな いが，リニ† IC およびディジタル IC を随所に用い て特性の改善と信頼度の向上を図っている。

用いられた IC の種類はリンャ ICでは 10〜50 $\mathrm{MHz}$ の周波数特性を持った早い演算增幅器之, $10^{4}$ 以 上の高利得演算増幅器, それにコンパレータ等であ る。早い演算增幅器は, Fig. 5 のリニヤ・アンプの中 間段に $50 \mathrm{MHz}$ の CA3030A が用いられており, Figs. 9〜11に示す IC 化ベースライン・レストアラに は $\mu \mathrm{A} 702$ か用いられている。り=+ IC は,大掁幅て 早いライズタイムが要求される用途に対しては適当な るのがなく、リニ+・フンプ等では限定された条件で 使われている。将来スリニウ・レートの大きな ICが得 られれば全面的に IC 化が考えられる。高利得の演算 増幅器は Fig. 2 の高圧電源や一般電源に用いられて おり，10 $10^{-4}$ オーダの特性が得られている。コンパレー タは Figs. 9 11 の振幅弁別回路等に用いて括り, 温度特性はきわめて安定でフルスケールのとき $2 \times$ $10^{-5} /{ }^{\circ} \mathrm{C}$ 以下である。リニヤ IC の問題点は, 入力端 子間の差動入力電圧が士 $5 \mathrm{~V}$ で制限されるため, +10 $\mathrm{V}$ をフルスケールとしているモジュール・システムに は不十分で, 入力信号を分割して使用しなければなら 
ない欠点がある。

次に、ディシタル IC は、スケーラなどディジタル 回路には全面的に使っており，Model 146 にはTTL. IC を, Model 160 には CML·IC を用いている。そ のほかディジタル IC 学用いている所は内部の補助的 パルス回路で，例完ば Model 136A, 133A，154A, 155 等の内部制御回路に用いている。これらの部分はプロ パゲーション・ディレイやその温度特性が問題になら ないところである。簡便に使える IC は RTL, DTL, TTL 等であるが，これらは飽和型であるためプロパ ゲーション・ディレイが大きく $(5 〜 40 \mathrm{nsec})$ ，温度特性 る $0.1 \sim 0.3 \mathrm{nsec} /{ }^{\circ} \mathrm{C}$ 出るので時間情報を直接扱うこと は問題で,この上5な部分はトランジスタのカレント ・スイッチ回路を用いている。

今後の IC 化についてはICの性能に期待され、リニ † ICではスリュー・レートが早くダイナミック・レン ジの大きなる，さらにパワーのとれるるのの出現が 望まれる。ディシタル IC では簡便で早いるのが期待 される。

11.むすび

ここ 1,2 年急增した需要に対処するため，回路内容 が十分検討されていないるのる1，2あるが，それらは 順次検討していきたいと考えている。今後の問題とし て，特性上は高分解能系を中心により吟味し，性能の 向上を計り， $\mathrm{ADC}$ やディジタル・スタビライザ,アナ ログ・ス、タビライザ,各種インスペクタ充実していき たいと考えている。それから計数系はまた不十分で， 中規模な自動測定がでさるよらな計数系に発展させ， さらにアナライザまたはコンピュータの周辺データ処 理系あるいはディジル・システムといった系を検討 する段階に来ているよ5に思われる。今後原研内の動 向とともに上記の方向の開発を進めていきたいと考え ている。
以上紹介した原研型モジュール・システムの開発は， 可内各研究室の指尊と拹力や，関係課の援助によって なし得たりので, これらの課坴に対しここに深く感謝 いたします。この開発の当初は高田稔 JPDR第三課長 (元ェレクトロニクス課長)，および現在では恩田利夫 課長加ら適切な指導を頂いている。現在もシュール。 システムの開発は, 設計係の諸氏および著者らによっ て試作設棓をを行い，山谷建三郎氏招よび技術係諸氏が 製作，調整を担当し，本田泰健氏拈よび業務係の諸氏 が対外接渉などをそれぞれ担当している。

本資料を主とるる当っては種々ご指尊とご協力を いただいた恩田課長および各担当諸氏に深く感謝いた しま卞。

\section{一参考文献—}

(1) EUR/C-IS/731/63, (Mar, 1963).

(2) TID-20893, (July 1964); Rev. 1, (Jan. 1966); Rev. 2, (Jan. 1968).

(3) 金原節朗，他：JAERI-memo 3768，(Oct. 1969).

(4) 同 上: JAERI-memo 2908, (Nov. 1967).

(5) 同 上: JAERI-memo 3165, (July 1968).

(6) 同 上: JAERI-memo 3375, (Jan. 1969).

(7) 同 上: JAERI-memo 3376, (Jan. 1969).

(8) 同 上: JAERI-memo 3605. (June 1969).

（9）金原節朗, 熊原忠士，猪俣新次：JAERI-memo 3160, (July 1968).

(10) Kinbara, S., KUmaHara, T, : Nucl. Instrum. Methods, 70, 173 (1969).

(11) 金原節朗, 熊原忠士，猪俣新次：JAERI-memo 3159, (July 1968).

(12) Kinbara, S., KumahaRA, T.: Nucl. Instrum. Methods, 67, 261 (1969).

(13) 金原節朗, 熊原忠士：原子力工業, 14[8], 45(1968).

(14) 熊原忠士: Radioisotopes, 17[10]，499 (1968).

(15) 金原節朗：同上, 17[10], 504 (1968).

(16) 熊原忠士：原子力工業，15[9]，25（1969）.

(17) 金原節朗：同 上, 15[9], 31 (1969). 